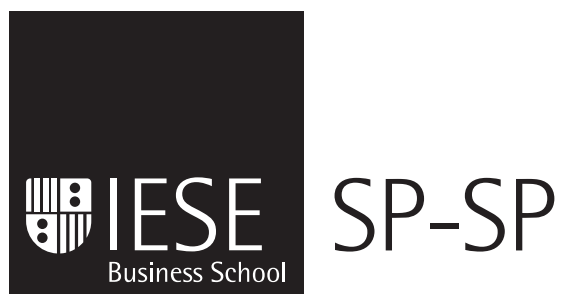

Working Paper

WP no 669

January, 2007

University of Navarra

\title{
APPROPRIATING VALUE FROM EXTERNAL TECHNOLOGY: ABSORPTIVE CAPACITY DIMENSIONS AND INNOVATION STRATEGY
}

\author{
Joan E. Ricart \\ Tunji Adegbesan
}


The Public-Private Center is a Research Center based at IESE Business School. Its mission is to develop research that analyses the relationships between the private and public sectors primarily in the following areas: regulation and competition, innovation, regional economy and industrial politics and health economics.

Research results are disseminated through publications, conferences and colloquia. These activities are aimed to foster cooperation between the private sector and public administrations, as well as the exchange of ideas and initiatives.

The sponsors of the SP-SP Center are the following:

- Accenture

- Ajuntament de Barcelona

- Official Chamber of Commerce, Industry and Navigation of Barcelona

- BBVA

- Diputació de Barcelona

- Garrigues, Abogados y Asesores Tributarios

- Catalan Government (Generalitat de Catalunya)

- Sanofi-Aventis

- Telefónica

- T-Systems

- VidaCaixa

The contents of this publication reflect the conclusions and findings of the individual authors, and not the opinions of the Center's sponsors. 


\title{
APPROPRIATING VALUE FROM EXTERNAL TECHNOLOGY: ABSORPTIVE CAPACITY DIMENSIONS AND INNOVATION STRATEGY
}

\author{
Joan E. Ricart* \\ Tunji Adegbesan**
}

\begin{abstract}
Innovation from external sources has continued to grow in importance in recent years, in defiance of conventional wisdom advocating internal sourcing of core technologies.

One important reason for the previous emphasis on internal sourcing of core technologies relates to concerns of horizontal and vertical appropriability. Thus the question arises of whether and how firms can reconcile horizontal and vertical appropriability with the rise of the external sourcing of new technologies. Must firms sacrifice value appropriation on the altar of value creation?
\end{abstract}

To answer these questions, we delve beneath individual technological innovations to examine the technical and market capabilities underlying them. Specifically, we show how the amount of value a firm stands to appropriate relative to competitors and relative to technology suppliers depends on the fit between its innovation strategy and its previous investments in distinct dimensions of absorptive capacity. At the same time, we also show how first-order capabilities and dynamic capabilities interact to determine firm performance. Thus we shed light on how and when the move to "open" innovation will affect the amount of value innovating firms stand to appropriate.

\footnotetext{
* Professor, General Management, Carl Schroder Chair on Strategic Management, IESE

** Ph.D. in Management, IESE
}

Keywords: Innovation strategy, external sourcing, technology innovation, value appropriation. 


\section{APPROPRIATING VALUE FROM EXTERNAL TECHNOLOGY: ABSORPTIVE CAPACITY DIMENSIONS AND INNOVATION STRATEGY*}

Innovation from external sources is on the rise. As markets for technology have appeared and flourished (Arora, Fosfuri, and Gambardella, 2001), "open innovation" has been promoted as a new paradigm for successful innovation (Chesbrough, 2003). Thus managers are increasingly accepting "that useful knowledge is widely distributed, and that even the most capable R\&D organizations must identify, connect to, and leverage external knowledge sources as a core process in innovation" (Chesbrough, 2006: 1).

One recent study, for example, found that an average of 45\% of innovation came from external sources, ranging from 30\% in pharmaceutical and chemical organizations, to as high as $90 \%$ in some retail companies (Linder, Jarvenpaa, and Davenport, 2003). In addition, while half of the executives surveyed believed that innovation from external sources would rise in the following three years, not a single one felt that it would decline (ibid.).

Nevertheless, one important reason for the previous emphasis on internal sourcing of core technologies can be found in concerns about horizontal and vertical appropriability. Conventional wisdom was that research in an organization's area of core expertise should stay in-house, while outsiders could only provide less important support activities. Yet businesses are now "using external sources for all phases of innovation, from discovery and development to commercialization and even product maintenance" (ibid: 44). What then happens to horizontal appropriability when firms source for new technologies in the same markets as their competitors?

In addition, according to strategic factor market theory, firms cannot profit from external resources unless they have superior expectations or are beneficiaries of good fortune (Barney, 1986). This suggests that vertical appropriability should be a problem for firms searching for valuable new technologies outside their borders. In other words, if expertise at the technological frontier has migrated beyond firm boundaries, how can firms have superior

\footnotetext{
* We would like to thank Bruno Cassiman, Margie Peteraf, Joaquim Vilà, and participants at the meeting of the Strategic Management Society in Orlando, for comments on this and earlier versions of the paper. We are also extremely grateful to Adam Brandenburger, Ramón Casadesus-Masanell, Glenn MacDonald, and Giovanni Valentini for ideas and suggestions on this and related work. Financial support from the Lagos Business School and the PublicPrivate Sector Research Centre (SP-SP) at IESE Business School-University of Navarra is gratefully acknowledged.
} 
expectations for such technologies, when they sometimes do not even know about their existence until suppliers offer them for sale?

Thus the question arises of whether and how firms can reconcile horizontal and vertical appropriability with the rise of the external sourcing of new technologies. Must firms sacrifice value appropriation on the altar of value creation? How can firms appropriate superior value relative to suppliers and competitors, when they innovate based on external technology?

To answer these questions, we delve beneath individual technological innovations to examine the technical and market capabilities underlying them. Specifically, we focus on the dynamic capabilities through which firms acquire, assimilate, transform and exploit new technologies, as well as the technological and market domains across which they leverage innovations.

In doing so, we build on the recent "bargaining perspective on resource advantage" (Lippman and Rumelt, 2003a) which integrates cooperative game theory into the resource-based view of the firm. In this approach, firms are seen as coalitions of co-specialized resources and capabilities, and value appropriation is the outcome of bargaining over surplus created between resources exhibiting some degree of complementarity. We also draw on Adegbesan (2005) who extends strategic factor market theory, using the bargaining perspective to account for situations (such as technological sourcing) where resource buyers display varying degrees of complementarity to target resources.

We thus show how the amount of value a firm stands to appropriate relative to competitors and relative to technology suppliers depends on the fit between its innovation strategy and its previous investments in distinct dimensions of absorptive capacity. At the same time, we also show how first-order capabilities and dynamic capabilities interact to determine firm performance. Thus we shed light on how and when the move to "open" innovation will affect the amount of value innovating firms stand to appropriate.

The rest of the paper is organized as follows. In the next section we briefly review the literature related to technology sourcing and value appropriation. Following this we present a resourcebased model of technological innovation, with the external sourcing of technology for innovation as one case of this general phenomenon. We then use the model to develop a capability-based typology of technological innovation, before going on to develop our theory relating innovation strategy and absorptive capacity to value appropriation. After deriving some falsifiable propositions, we discuss the implications, limitations, and extensions of the paper, before concluding.

\section{Value Appropriation and the Performance Impact of Technological Innovation}

The need for a focus on the amount of value appropriated from technological innovation has recently become more pressing (McEvily, Eisenhardt, and Prescott, 2004). Scholars as well as managers are increasingly concerned as "evidence is growing that innovation processes in many industries are not yielding the benefits they should" (Linder et al., 2003: 43). Even though measures of innovativeness have increased, economic performance has not improved correspondingly (Kandybin and Kihn, 2004; Linder et al., 2003). Consequently it is likely that many innovators are not capturing much of the value created by their innovations. 
"The key determinant of the profitability of an innovation to the innovator is the share of the value created by that innovation, that the innovator is able to appropriate" (Grant, 2002: 335). It is therefore important to have a better understanding of the determinants of the amount of value an innovator stands to appropriate from successful technological innovation.

\section{Technology Sourcing and Value Appropriation}

Value appropriation acquires even greater importance in view of the recent growth in the external sourcing of technology for innovation. As technological change has accelerated, and the number and mobility of knowledge workers (along with their access to venture capital) has reached unprecedented levels, firms have come to depend more and more on knowledge developed beyond their borders (Quinn, 2000; Robertson and Gatignon, 1998; Veugelers, 1997). The growth of markets for technology has given firms more options for the external acquisition of new technology to embody in products and processes (Arora et al., 2001).

Firms that open up to external technology inflows can access a greater variety of innovative ideas more speedily, and thus cope better with technological change (Chesbrough, 2003; Rigby and Zook, 2002; Rothaermel, 2001). External sourcing allows firms to share the risks and costs of R\&D, while exploiting complementarities between internal and external knowledge (Arora and Gambardella, 1994; Cassiman and Veugelers, 2002). By providing faster access to new technologies, external sourcing also helps firms to speed up their innovation development process, and can help to stimulate internal innovativeness (Robertson and Gatignon, 1998; Veugelers, 1997). Thus it is no surprise that firms are increasingly seeking inputs to the innovation process from beyond their borders. In fact managers and scholars are urged to embrace a new paradigm of "open innovation" (Chesbrough, 2003) or "open-market innovation" (Rigby and Zook, 2002) in response to the new competitive environment (Chesbrough, Vanhaverbeke, and West, 2006; Laursen and Salter, 2006).

Nevertheless the advantages of external technology are not a new discovery, as the study of the pros and cons of external sourcing goes back at least as far as von Hippel (1982) and Williamson (1985). Along with the above-cited advantages, previous work has uncovered considerable disadvantages, such as higher transaction costs, weaker seller incentives, supplier opportunism and the threat of hold-up, increased ease of duplication by competitors, and "indigestibility" of external technology (e.g. Ghemawat, 1991; Pisano, 1990; Reuer and Koza, 2000; Robertson and Gatignon, 1998; Williamson, 1985). In particular, the issue of appropriability looms large (Ghemawat, 1991). Horizontally, firms that depend on external sourcing are often unable to prevent competitors from accessing such technologies as well (Ghemawat, 1986; Levin, Klevorick, Nelson, and Winter, 1987). Vertically, unless firms have better foresight than technology suppliers, all the potential value to be created will be anticipated in the technology's purchase price (Barney, 1986; Makadok and Barney, 2001).

Thus it is puzzling that so little work has looked at what the increased emphasis on external sourcing portends for value appropriation (West, 2006). The many advantages of an "open innovation" paradigm simultaneously lead to increased concerns about the appropriability of value created when firms innovate based on externally sourced technology. When firms open up their borders to external inflows and outflows, competitors, suppliers, customers, and complementors can all lay claim to a portion of value created (Brandenburger and Nalebuff, 1996; Teece, 1987). How then can firms ensure they appropriate a substantial part of the value created when they embody external technologies in innovative products? Or is weakened appropriability a reality firms have to accept as the price for increased innovativeness? 


\section{Inimitability and Value Appropriation}

Research on the appropriability of value created by technological innovation has been strongly influenced by David Teece's seminal paper. In explaining the failure of innovative firms, Teece argued that under a "weak appropriability regime," "markets don't work well, and the profits from innovation may accrue to the owners of certain complementary assets, rather than to the developers of the intellectual property" (Teece, 1987: 185). According to Teece, the strength of the "appropriability regime" is a function of the legal mechanisms available to protect innovation, and the knowledge characteristics of the underlying technology (ibid.); and thus it is a measure of the imitability of the innovation. As such, value appropriation depends on the ability to prevent imitation or replication of an innovation, barring which the critical determinant becomes the ability to achieve a superior position in the required complementary assets for commercializing the innovation (ibid.).

Studies by scholars in the economic tradition have highlighted different legal mechanisms for avoiding imitation, as well as their relative effectiveness (e.g. Cohen, Nelson, and Walsh, 2000; Levin et al., 1987; Winter, 2000a). In this line of work, "perfect appropriability" is equated with "monopoly of the invention" (Levin et al., 1987: 783); and "appropriation mechanisms" studied include patents, trade secrets, trademarks, and copyrights; as well as other factors such as lead time, and plain secrecy (Arora, Ceccagnoli, and Cohen, 2003; Cohen et al., 2000; Levin et al., 1987). Scholars in this area have shown that the relative effectiveness of each of these mechanisms varies widely across industries as well as across product or process innovations (ibid.).

Other scholars have looked at the second factor affecting Teece's "appropriability regime": the characteristics of the underlying technology. Burgelman, Maidique, and Wheelwright (2001: 4) define technology as "the theoretical and practical knowledge, skills, and artefacts that can be used to develop products and services as well as their production and delivery systems." Thus the knowledge characteristics of the new technology underlying an innovation can impede imitation (Kogut and Zander, 1992; Reed and DeFillipi, 1990). Specifically, the imitability of an innovation depends on its degree of social and/or technical complexity and its resource- or context-specificity; as well as on whether its underlying knowledge is tacit or codified, observable or non-observable in use, and whether or not it requires tangible assets for deployment (Argyris and Schon, 1978; Maritan and Brush, 2003; McEvily and Chakravarthy, 2002; Nelson and Winter, 1982; Polanyi, 1962; Szulanski, 1996; Teece, 2003).

Nonetheless, applying these insights to innovation based on externally sourced new technologies causes at least three problems. Firstly, most current work focuses on the ability of the technology supplier to appropriate value from a new technology. Under the paradigm of "closed innovation" (Chesbrough, 2003) it was relatively uncommon for firms to innovate based on external technologies. On the other hand, in a paradigm of "open innovation" (Chesbrough et al., 2006) we also need to examine whether and how a firm that embodies external technologies in new products and/or processes can appropriate a significant share of the value thus created.

Secondly, the emphasis on inimitability addresses horizontal appropriability, while neglecting vertical appropriability somewhat. When firms innovate based on externally sourced technology, there remains the possibility of upstream "hold-up" (Ghemawat, 1991) by technology suppliers. Thus monopoly can no longer be equated to "perfect appropriability." ${ }^{1}$ In one study for example,

\footnotetext{
${ }^{1}$ Work by Coff and others (Ahuja, Coff, and Lee, 2005; Coff, 1999; Coff and Lee, 2003) shows that even without external sourcing, firms can still be held up by "internal suppliers.”
}

4 - IESE Business School-University of Navarra 
Caves, Crookell, and Killing (1983: 258) found that bargaining and "dubiously appropriating variables" accounted for up to 50\% of payments to upstream suppliers. On the downstream end, Kreps (1990: 314-315) ${ }^{2}$ has pointed out that the assumption that a monopoly can extract all the value created from consumers is not unassailable.

Finally, with open innovation firms cannot count on the ability to exclude competitors from externally sourced new technologies, making inimitability even more difficult. Thus innovating firms may have to focus on the complementary capabilities that enable them to profit more than rivals from technological innovation. As such, we need to look beyond the innovative technologies and products in question, to the underlying capabilities by means of which they are molded and leveraged across multiple domains. Additionally, since value appropriation results from simultaneous vertical and horizontal competition involving innovating firms, buyers, and suppliers, its analysis requires a theoretical approach capable of handling this multi-level plurality of stakeholders, as well as an emphasis on firm-level performance outcomes. For these two reasons, we turn to a recent extension of the resource-based view of the firm.

\section{Value Appropriation and the Bargaining Perspective on Resource Advantage}

The resource-based view (RBV) conceptualizes firms as bundles or coalitions of resources, assuming that firms within an industry might be heterogeneous with respect to the strategic resources they control, and that these resources may not be perfectly mobile across firms (Barney, 1991; Lippman and Rumelt, 2003a; Peteraf, 1993). A defining feature of the RBV is that it gives "an efficiency-based explanation of performance differences, rather than one relying purely on market power, collusion, or 'strategic' behaviours" (Peteraf and Barney, 2003: 311). As such "performance differences are viewed as derived from rent differentials, attributable to resources having intrinsically different levels of efficiency" (Peteraf and Barney, 2003: 311; Barney, 1991; Peteraf, 1993).

One of the least developed areas of the RBV however, relates to the conditions under which firms can appropriate value created by the combination and deployment of resources (Coff, 1999; Denrell, Fang, and Winter, 2003; Hoopes, Madsen, and Walker, 2003). Despite the fact that value appropriation is critical to the RBV's interest in explaining why firms in the same industry vary systematically in performance over time (Hoopes et al., 2003), "rent appropriation is an under-researched area at the core of the resource-based view and the strategy literature" (Coff and Lee, 2003: 183-184).

Lippman and Rumelt (2003a, b) hold that this and other issues can be better addressed by integrating cooperative game theory into the micro-foundations of the RBV. According to them, theoretical researchers in competitive strategy have developed the RBV upon the microfoundations $^{3}$ of standard neoclassical economics (Lippman and Rumelt, 2003a). Nevertheless when resources exhibit varying degrees of complementarity (as in external technology sourcing), the relative demand and supply of sellers and buyers along with the various combinatorial possibilities, create a complex situation that standard neoclassical economics-based approaches cannot handle (Denrell et al., 2003; Lippman and Rumelt, 2003a, b; Makowski and Ostroy, 2001).

\footnotetext{
${ }^{2}$ Cited in Brandenburger and Stuart (2003).

3 "The micro-foundations of a subject are the definitions of its basic elements and the allowable operations that can be performed using these elements" (Lippman and Rumelt, 2003b: 903).
} 
Since such conditions are among those of greatest interest to researchers in the RBV, they propose a "bargaining perspective on resource advantage" (Lippman and Rumelt, 2003a), built on the foundations of a "payments perspective" (Lippman and Rumelt, 2003b).

In this approach, rents appear as negotiated payments for the services of scarce valuable resources. The bargaining perspective "separates the issues of opportunity cost, value, and the distribution of rents," providing "a formal system in which surplus is known, but its division is subject to negotiation" (Lippman and Rumelt, 2003a: 1070). Firms are seen as coalitions of resources and "no resource is "firm specific." Instead "there are co-specialized resources that exist within the legal shell of the firm" such that "bargaining parties are not firms or products, but rather the individual resources that lie behind them" (ibid.). The division of surplus is formally indeterminate and will be determined by the relative values created by different use combinations of resources. Thus at the heart of this approach is bargaining over the sharing of surplus created by resource combination.

This synthesis is both elegant and effective, because while solution concepts from cooperative game theory provide an excellent approach for studying the division of surplus, the RBV's focus on resource advantage highlights the impact of resource endowments on this division. Nevertheless one should point out that cooperative game theory had already been fruitfully used in strategy research. Brandenburger and Stuart (1996) were the first to import the coalitional approach into strategic management, and they showed it to be a powerful tool for analyzing value appropriation issues. Recent usage of coalitional models in strategy can also be found in papers by MacDonald and Ryall (2003; 2004), Brandenburger and Stuart (2004), and Stuart (2001) among others.

In this paper we build on the bargaining perspective to conceptualize technological innovation as the outcome of the combination of resources and capabilities with some degree of cospecialization. When technological innovation is based on externally sourced technology, there will be coalitional bargaining over the surplus created, resulting in differential value appropriation. Using the theory developed by Adegbesan (2005), we then relate the learning characteristics of the innovation and firms' absorptive capacity endowments to individual firms' bargaining positions, and thus to the amount of value they stand to appropriate.

In the next section we present a resource-based model of technological innovation, and introduce a classification of a firm's innovation strategy. With that done, we then proceed to the analysis of the determinants of the amount of value appropriated from technological innovation based on externally sourced technology.

\section{A Resource-based Model of Technological Innovation}

Innovation is the embodiment of new approaches to doing business in products/services and/or their production and delivery systems (Burgelman et al., 2001; Grant, 2002). However, these "new approaches" may have different foci. Thus an innovation's novelty may arise from "new approaches" to technology, firm organization, financing, or business models, embodied in products or processes. Consequently innovation can be technological, organizational, financial, or may relate to business concepts/models (Drucker, 1985; Grant, 2002; Hamel, 2000; Kim and Mauborgne, 1999; Markides, 1997), to name a few possibilities.

In this line, we define technological innovation as the embodiment of technical advances or new technologies in products and/or their production and delivery systems. As technical 
advancement has quickened, firms have increasingly sought to create enhanced value through the embodiment of new technologies in products and processes. Thus technological innovation is not just the commercialization of new technologies, but innovation, where the focus of the novelty is technological. In other words, while technological innovation for a microprocessor manufacturer might involve the production of some new advanced semiconductor chip, technological innovation for a bank might involve using new technologies to provide clients with rich financial information via their mobile phones. For this reason, it is not confined to "high technology" industries but is, in Drucker's words, "as important to a bank, an insurance company or a retail store, as it is to a manufacturing or engineering business" (Drucker, 1954: 40). The end product of technological innovation may thus not be a technology itself, but will embody at least some new technology or technical advance.

\section{Technological Innovation as Resource and Capability Combination}

The resource-based view sees the firm as a bundle or coalition of resources (Barney, 1991; Lippman and Rumelt, 2003a; Peteraf, 1993). In the bargaining perspective, a firm's legal shell contains a co-specialized bundle of resources and capabilities (Lippman and Rumelt, 2003a). "A resource is an observable (but not necessarily tangible) asset that can be valued and traded such as a brand, a patent, a parcel of land" (Hoopes et al., 2003: 890; Makadok, 2001) or a technology. On the other hand, a capability "is not observable (and hence necessarily intangible), cannot be valued and changes hands only as part of its entire unit" (ibid.).

Danneels (2002) considers the development of an innovation as entailing the "linking" of technological and customer capabilities within a firm. In a similar way, we conceptualize technological innovation as the outcome of the combination of resources and capabilities, including new technology, technical and market capabilities, and other firm resources, within or across firms (Clark, 1987; Danneels, 2002; Nerkar and Roberts, 2004). In other words, the creation of products embodying new technologies will require a process of combination of at least the following series of distinct resources and capabilities: the new technology, firm technical capabilities, firm market capabilities, and other firm resources/capabilities. Each of these may exist within the firm to varying degrees, and thus may have to be augmented via learning or acquisition from beyond the firm's boundaries. This view is summarized in Figure 1.

\section{Figure 1. A Resource-based Model of Technological Innovation}

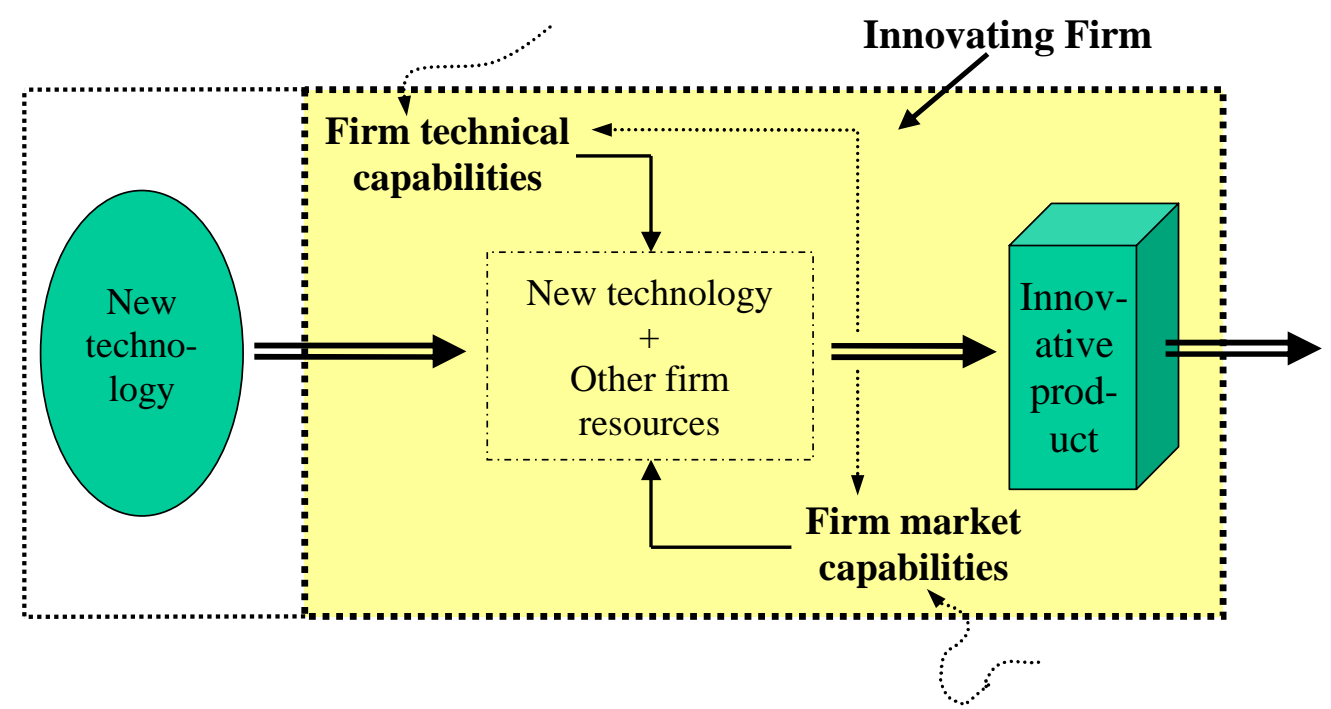

IESE Business School-University of Navarra - 7 
As the figure shows, technological innovation entails the combination of new technology with other firm resources. This integrative linking requires the application of a firm's technical and market capabilities (Clark, 1987). Thus the value of the innovative product created by a given firm will also depend on the quality of the technical and market capabilities (and other firm resources) brought into play in its creation (Henderson and Cockburn, 1994).

The depiction of a "semi-permeable" firm boundary permits the consideration of technological innovation based on externally sourced new technology as one case of the more general phenomenon of technological innovation. Nevertheless, regardless of whether the new technology is sourced internally or externally, internal resources and capabilities remain critical.

Finally, the dotted feedback arrows in Figure 1 reflect firms' ability to improve their capabilities by learning from both internal and external sources. Successful innovation leads to greater learning, as some necessary technical or market capabilities may have to be sourced from outside the firm (Danneels, 2002), and over time firms may develop expertise in given technological or/and market domains (Nerkar and Roberts, 2004).

As an illustration, we can consider radio frequency identification (RFID) a new technology that consists of minute semiconductor chips which, when implanted in various materials, can wirelessly emit signals containing information such as identification numbers, age (of the chip), location etc. Imagine that Wal-Mart were to implant such devices in customers' loyalty cards. On entering a store, a bearer of one of these cards might receive information on new arrivals, discounts and rebates etc. on her mobile device, based on previous purchasing history. ${ }^{4}$ To create this innovative service, Wal-Mart would require not only the acquisition of the RFIDenabled cards (the new technology) but would also need to get customers to sign-on to the service, capture customer data as well as all its own supply chain data in its information systems, possibly sign agreements with wireless telephony operators, inform key privacy rights groups, etc. Thus, without the deployment of other vital resources and capabilities, the new technology on its own would not lead to successful technological innovation.

Two implications of this approach arise. Firstly, technological innovation does not require the innovating firm to be a technology firm itself. Technological innovation can be based on externally sourced technology, once it is embodied in firm products or processes, and forms their locus of novelty. Secondly, differing degrees of complementarity between the new technology and other firm resources, means that different bundles of co-specialized resources and capabilities (firms) may create differing amounts of value when they innovate based on the same technology. Thus firm $i$ might use externally sourced technology to create a surplus $\Delta V_{i}$, while firm $j$ uses the same technology to create $\Delta V_{j}$ where $\Delta V_{j}>\Delta V_{i}$, because firm $j$ 's bundle of co-specialized resources exhibits greater complementarity to the new technology.

\section{Capability Exploitation and Exploration in Technological Innovation}

In order to explore the role that capability differences play when firms have access to the same external technologies, we characterize technological innovation in terms of the degree to which it builds on current firm capabilities, or requires the learning of new ones.

Our characterization follows Danneels (2002) and Dougherty (1992), who view innovation as a process of linking technologies and markets. Since innovative products embody specific

\footnotetext{
${ }^{4}$ This idea exists only in our imagination as far as we know.
} 
technologies and are directed at specific markets, they "constitute the integration of markets and technologies" (Dougherty, 1992: 78) and thus depend heavily on firms' underlying market and technical capabilities. To the extent that a technological innovation requires technical or market capabilities in which a firm is deficient, its successful creation entails the learning of the necessary capabilities, and for this reason innovation is also a mechanism for organizational renewal (Danneels, 2002; Dougherty, 1992).

This learning can be exploratory or exploitative, (March, 1991) depending on the extent to which it builds on capabilities in which a firm is already proficient. Thus, although in terms of its tangible output innovation always connotes some novelty and "exploration," at the level of the technical and market capabilities called into play in its creation, learning can range from "pure exploitation" to "pure exploration" (Danneels, 2002: 1105; March, 1991). Therefore applying Danneels's typology to our definition of technological innovation we distinguish between exploitative, technical capability leveraging, market capability leveraging, and exploratory technological innovation, as summarized ${ }^{5}$ in Figure 2.

\section{Figure 2: Capability-based Technological Innovation Typology}

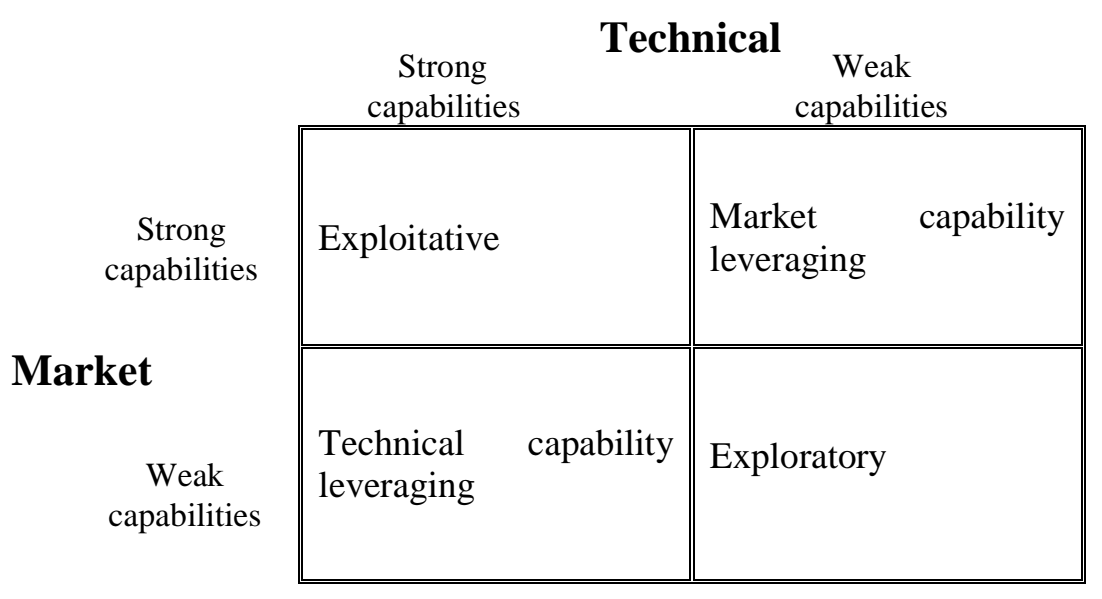

As Figure 2 shows, when a new technology belongs to a technological domain in which a firm has strong technical capabilities, and it is embodied in a product that addresses a market for which the firm has well-developed capabilities, then we refer to an exploitative technological innovation. If however a firm has weak technical capabilities in the relevant technological domain, and weak market capabilities for the customers addressed, then we refer to an exploratory technological innovation. In the first case the firm's innovation exploits both its current technical and market capabilities while in the second case it explores new technical and market capabilities.

On the other hand, when a technological innovation is exploitative of market capabilities but explorative in terms of technical capabilities, we refer to it as a market capability leveraging technological innovation. Similarly, a technical capability leveraging technological innovation

\footnotetext{
${ }^{5}$ Adapted from Danneels (2002).
} 
occurs when firm capabilities are strong in the relevant technological domain but weak in the market addressed.

It should be noted that this characterization of technological innovation is relative to the capabilities of a focal innovating firm. Heterogeneous resource and capability endowments coupled with path dependency (Barney, 1991), can cause what constitutes an exploitative technological innovation for one firm to constitute, say, a market capability leveraging innovation for another. For example, pharmaceutical firms have to allocate limited R\&D dollars across many subfields of biotechnology. Thus the development of a new drug based on published advances in a given subfield (e.g. gene sequencing) could be an exploitative innovation for a given pharmaceutical firm that has invested heavily in basic research in that area, if the drug is directed at a therapeutic market (e.g. breast cancer patients) with which it has extensive experience. However, the development of a drug based on the same scientific advances can constitute a market capability leveraging innovation for some other pharmaceutical firm that has modest expertise in gene sequencing, but intends to use it to develop drugs for breast cancer patients, a therapeutic market with which it is very familiar as well.

Nevertheless, one can also imagine situations where the knowledge-base and learning characteristics of a technological innovation are similar for all or most firms in a particular market. In this line, for instance, one could argue that the provision of Internet-based banking services for major corporate clients was an exploitative technological innovation for most large banks which had already invested heavily in information/communication technologies.

Our typology can also be related to work by Katila and Ahuja (2002) who consider firms' "search depth" and "search scope" in new product introduction. While our focus on the degree of capability learning required by an innovation can be considered analogous to their dimension of "search depth," we go beyond technological "search" to consider the market dimension as well.

Another important study, by Rosenkopf and Nerkar (2001), considers whether firm exploration spans technological and/or organizational boundaries. In our case, the focus on external sourcing of new technologies means that organizational boundaries are always spanned. However, technological boundaries may or may not be spanned; as such new technologies may belong to technological domains in which firms already have strong capabilities. In addition, along with technological characteristics, our typology also considers the extent to which market capability boundaries are "spanned" as well.

Using our characterization, we consider a firm's innovation strategy in terms of which technologies it chooses to access externally, and which markets it chooses to deploy them in. In other words, a firm's innovation strategy determines whether it pursues exploitative, exploratory, or market/technical capability leveraging technological innovation. While previous work has considered the implications of innovation strategy for innovativeness and the level of innovative output observed, we focus on how this choice affects the amount a firm stands to appropriate from the value created by such innovative output.

Next we briefly review research on the dimensions of absorptive capacity, before going on to show how these interact with a firm's innovation strategy to shape value appropriation. 


\section{Dimensions of Absorptive Capacity}

Absorptive capacity was introduced by Cohen and Levinthal $(1989,1990)$ as a critical factor in firms' attempts to utilize external knowledge to spur internal innovation. Defining absorptive capacity as a firm's ability to recognize the value of new information, assimilate it, and apply it to commercial ends (Cohen and Levinthal, 1990), they argued that it was largely a function of prior related knowledge, and was critical for firms' innovative capabilities. Absorptive capacity has since been very widely used as a predictor of innovative output at firm (e.g. Cockburn and Henderson, 1998; Mowery, Oxley, and Silverman, 1996), inter-firm (e.g. Lane and Lubatkin, 1998; Lane, Salk, and Lyles, 2001), and intra-firm (e.g. Lenox and King, 2004; Tsai, 2001) levels.

Recently however, Zahra and George proposed conceptualizing absorptive capacity as a dynamic capability (Eisenhardt and Martin, 2000; Teece, Pisano, and Shuen, 1997; Winter, 2003), "pertaining to knowledge creation and utilization" (Zahra and George, 2002: 185). They suggested considering it as consisting of the four dimensions of knowledge acquisition, assimilation, transformation, and exploitation. In their scheme, knowledge acquisition and assimilation constitute potential absorptive capacity, while knowledge transformation and exploitation constitute realized absorptive capacity.

Zahra and George argue that their "reconceptualization" will help to focus empirical attention on potential absorptive capacity, which they believe has been neglected in previous work, relative to realized absorptive capacity. They also hold that conceptualizing absorptive capacity as a dynamic capability helps to relate the construct more closely to broader research on firm capabilities within the RBV. Finally, they believe that viewing absorptive capacity as a dynamic capability makes it more "amenable to change through managerial actions that redefine and deploy the firm's knowledge-based assets” (2002: 186).

It could be argued that in Zahra and George's scheme, while other dimensions are accounted for, the knowledge valuation dimension as well as the domain-specific nature of absorptive capacity (both emphasized by Cohen and Levinthal), are not very explicit. Nevertheless, their approach has other advantages for research on firm capabilities in general, and for this paper in particular. Firstly their conceptualization of absorptive capacity as a dynamic capability is very useful for our focus on the capabilities underlying technological innovation. Since dynamic capabilities act upon firms' "zero-level" capabilities (Winter, 2003), we expect them to interact with the capability-learning characteristics of technological innovation (Winter, 2000b) in determining value appropriation. Secondly, Zahra and George's approach helps to shed light on possible loci of differences in absorptive capacity endowments between firms. Inter-firm variation in absorptive capacity can arise as some firms invest more heavily in potential than realized absorptive capacity or vice-versa (Jansen, Van Den Bosch, and Volberda, 2005).

In this paper, we focus on the distinct roles of potential and realized absorptive capacity, relating both of them to value appropriation. While most previous work has considered absorptive capacity as a driver of innovative capabilities and innovative output (Zahra and George, 2002), we suggest that absorptive capacity can also act as an appropriation mechanism.

\section{Appropriating Value From External Technology}

To address value appropriation from technological innovation based on externally sourced technology, we consider a double-sided strategic factor market for new technologies (Arora 
et al., 2001; Barney, 1986). Barney defines a strategic factor market as "a market where the resources necessary to implement a strategy are acquired" (1986: 1231). Hence in this case the strategy in question is technological innovation, while the necessary resource is a new technology.

Our double-sided market has suppliers of technology on one side, and firms seeking to embody new technologies in products and processes on the other (Lippman and Rumelt, 2003a; Adegbesan, 2005). The technologies available vary in their supply and may span multiple technological domains. While technology suppliers seek to sell to firms with which they can create the most value, innovating firms seek to acquire valuable technology at the best possible price. Nevertheless, innovating firms are also in competition amongst themselves, as they seek superior performance through innovative products and services directed at various markets.

Innovating firms are regarded as heterogeneous bundles of resources and capabilities exhibiting some degree of co-specialization (Lippman and Rumelt, 2003a). Since technological innovation requires the combination of new technology and other firm resources and capabilities, innovating firms vary in their complementarity to the new technologies available.

When technical advancement leads to the appearance of a particular new technology in the market, a number of firms may seek to incorporate it in innovative products or services. The number of firms seeking to innovate with the technology will depend on the firms' innovation strategies and the availability of the technology in question. How then is the value created with this new technology shared between innovating firms and technology suppliers? Additionally, how does value appropriation vary across individual innovating firms?

\section{Bargaining Over Value in Strategic Factor Markets}

We analyze the determinants of value appropriation, drawing on work by Adegbesan (2005) that extends strategic factor market theory (Barney, 1986; Makadok and Barney, 2001) to account for situations where buyers display varying degrees of complementarity to target resources (Lippman and Rumelt, 2003a). The prevalent view in research on strategic factor markets has been that firms cannot appropriate gains from the deployment of valuable resources unless they have superior expectations about their future value, or they benefit from luck (Ahuja et al., 2005; Barney, 1986; Denrell et al., 2003; Makadok and Barney, 2001). Nevertheless, despite its broad acceptance, this conclusion is true only when there are no complementarities between resources (Adegbesan, 2005; Barney, 1988; Conner, 1991; Lippman and Rumelt, 2003a).

When there are no complementarities between resources, if the value of a resource $R_{1}$ on its own is $v\left(\mathrm{R}_{1}\right)$ and the value of another resource $\mathrm{R}_{2}$ is $v\left(\mathrm{R}_{2}\right)$, then in combination their value is at most $v\left(\mathrm{R}_{1} \cup \mathrm{R}_{2}\right)=v\left(\mathrm{R}_{1}\right)+v\left(\mathrm{R}_{2}\right)$. Thus $v\left(\mathrm{R}_{1}\right)$ would be the marginal productivity of $\mathrm{R}_{1}$ in the combination, and Barney's (1986) logic holds: unless the supplier of $R_{1}$ doesn't know what it is worth (asymmetric information), the owner of $\mathrm{R}_{2}$ cannot pay less than $v\left(\mathrm{R}_{1}\right)$ for the services of $R_{1}$. As such, a resource buyer cannot get more than she pays for.

However, when there is some degree of co-specialization (complementarity) between the resources, their combination is "superadditive," and $v\left(\mathrm{R}_{1} \cup \mathrm{R}_{2}\right)=v\left(\mathrm{R}_{1}\right)+v\left(\mathrm{R}_{2}\right)+\Delta V$ where $\Delta V>0$ (Adegbesan, 2005; Thomke and Kuemmerle, 2002). The magnitude of the surplus created $(\Delta V)$ is proportional to the degree of complementarity between the resources. It does not "belong" to either resource, but results from their combination, and the way it is split between them 
is therefore indeterminate ex ante. Thus if the owner of $R_{2}$ is able to appropriate a positive share of the surplus $\Delta V$, she can realize gains to trade even if she had to pay $v\left(\mathrm{R}_{1}\right)$ for the services of $\mathrm{R}_{1}$.

Adegbesan (2005) builds on the bargaining perspective to show that the portion of surplus captured by each player depends on the joint effects of the relative supply/demand of seller and buyer groups; the relative degree of complementarity between individual buyers and target resources; and the bargaining ability of individual buyers relative to individual resource suppliers.

This is illustrated ${ }^{6}$ in Figure 3 in the context of technological innovation by a firm $j$ using new technology from a supplier $i$. The surplus so created $\left(\Delta V_{i j}\right)$ is split between them such that $\Delta V_{i j}=$ $u_{i}+v_{j}$. Adegbesan (2005) formally shows that some of the surplus will be guaranteed to the scarcer partner in proportion to the value it could create with the most valuable unmatched player $\left(\delta_{0}\right)$; some will be guaranteed to the bidding partner in proportion to its superior complementarity relative to its least valuable matched peer $\left(\Delta V_{i j}-\delta_{1}\right)$; and a final portion is split within each pair, according to the partners' relative bargaining ability $\left(\delta_{1}-\delta_{0}\right)$. Thus, all else being equal, the greater a partner's relative scarcity, superior complementarity, or relative bargaining ability, the greater the amount of value it will appropriate.

\section{Figure 3: Competition and Bargaining in Value Appropriation}

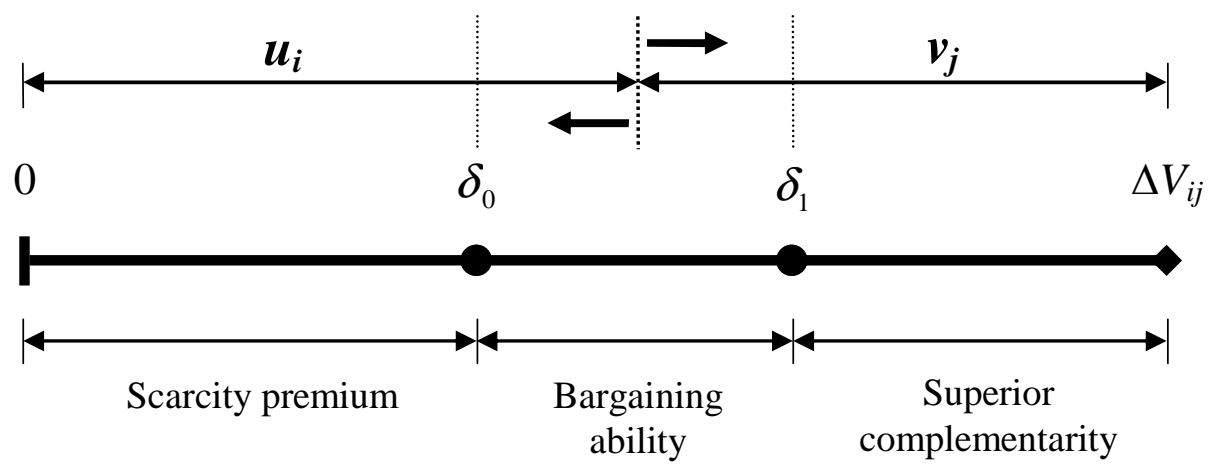

We use this bargaining model to link firms' innovation strategies and absorptive capacity endowments to the amount of value they can appropriate from external technology. In particular we focus on the mediating impact of relative complementarity, as illustrated in Figure 4. Firm first-order as well as dynamic capabilities determine their ability to create value with specific technologies in specific markets, and thus their degree of complementarity. Since firms with superior complementarity stand to appropriate more value, the decision of which technologies to source and which markets to deploy them in will interact with capability endowments to produce value appropriation outcomes.

\footnotetext{
${ }^{6}$ Illustration from Adegbesan (2005).
} 


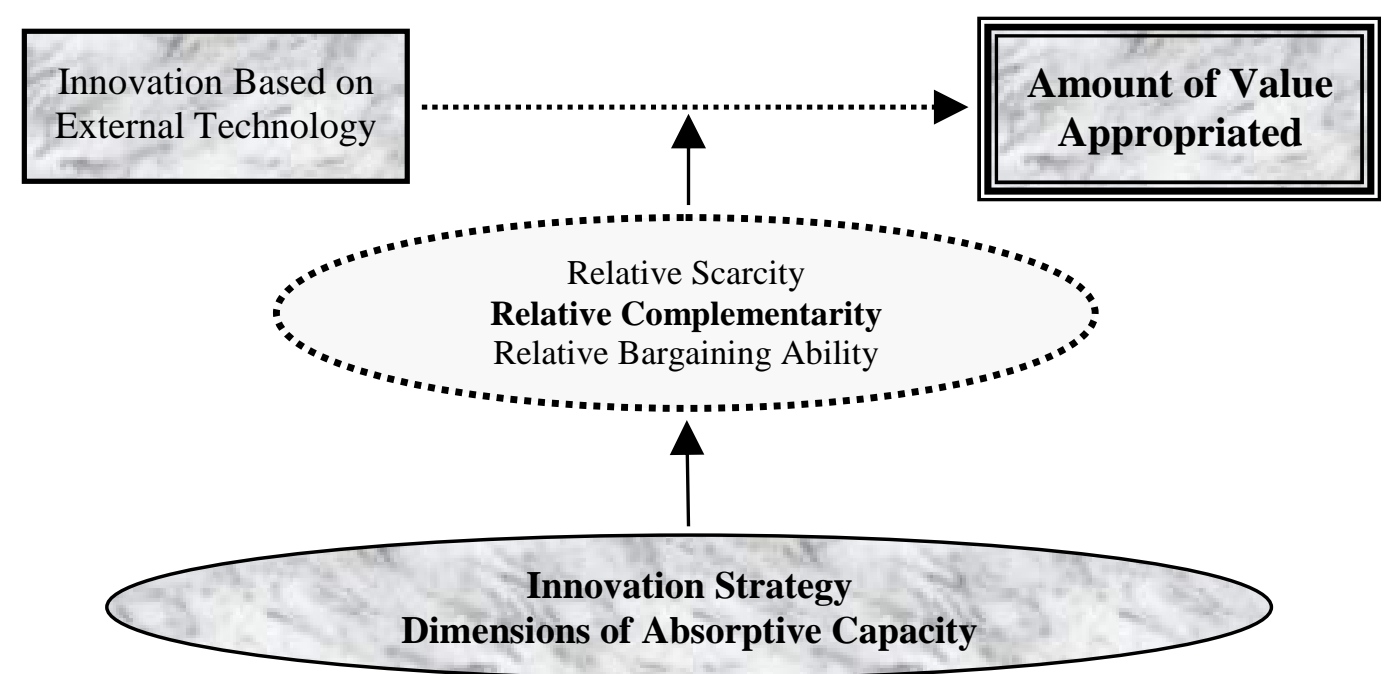

\section{Capabilities, Learning, and Value Appropriation}

Innovation based on externally sourced technology requires the acquisition and assimilation of new technologies, as well as their transformation and embodiment in products directed at specific markets. Firm technical and market capabilities are essential for effectively absorbing new technology, combining it with other resources and capabilities, and exploiting it in products that create value for customers (Danneels, 2002; Nerkar and Roberts, 2004).

When firms have well-developed technical capabilities in the same domain as a new technology, they are able to speedily and efficiently acquire and assimilate it, as a result of their minimal learning requirements (Zahra and George, 2002). Their similar knowledge base, and their highly honed routines for working with technologies in that domain, will lead to innovations of high technical quality (Clark, 1987).

Similarly, when they have well-developed competencies in the market addressed, they are able to transform and exploit new technologies in products that create superior value. Their deep understanding of customer needs, along with their refined marketing capabilities, permit them to transform new technologies into products that customers value highly (Clark, 1987; Danneels, 2002). In other words, firms pursuing exploitative technological innovation are able to create products of a high technical quality that satisfy real customer needs in the markets addressed, and thus display a high degree of complementarity.

However, when firms pursue capability leveraging technological innovation, the innovation process requires them to augment their technical or market capabilities through learning (Rosenkopf and Nerkar, 2001). Unlike firms that have highly honed routines for working in given technological domains or markets, firms that have to learn while on the job will not be as effective in producing innovations of high technical quality or market value. Thus firms that pursue capability leveraging technological innovation will exhibit less complementarity than firms pursuing exploitative technological innovation, but greater complementarity than firms pursuing exploratory technological innovation. As such: 
Proposition 1: When firms embody a new technology in successful products addressing a given market, those firms pursuing exploitative technological innovation will appropriate more value than firms pursuing capability leveraging technological innovation, and the latter will appropriate more value than firms pursuing exploratory technological innovation.

Although value appropriation is maximized by following a strategy of exploitative technological innovation, firms may trade appropriation benefits for learning benefits, in order to avoid competency traps (March, 1991) associated with excessive exploitation. Thus it is not enough to look at how appropriation varies across strategies, but it is also important to consider its variation within particular innovation strategies. Given the choice of a particular innovation strategy, what determines a firm's ability to appropriate superior value?

Market capability leveraging technological innovation. Firms pursuing market capability leveraging technological innovation seek to exploit their capabilities in a given market, while exploring new technical capabilities. As a result of their strong market capabilities, such firms will have a good knowledge of customer needs and preferences, in addition to complementary resources for addressing such a market (Clark, 1987).

Nevertheless, their lack of prior related technological knowledge can hamper efforts to acquire and assimilate the new technology, while their established technological routines can act as core rigidities in working with the new technology (Cohen and Levinthal, 1990; LeonardBarton, 1992). Additionally, poor capabilities in the new technological domain can make it difficult for them to accurately assess technical requirements, while increasing the required search scope for technological learning (Danneels, 2002; Katila and Ahuja, 2002).

These problems can be reduced considerably if firms have strong knowledge acquisition and assimilation capabilities. Firms with well-developed knowledge acquisition capabilities are more receptive to new technological knowledge (Zahra and George, 2002). They are faster at incorporating new information into their knowledge-bases, and are more intense in their knowledge acquisition efforts (Kim, 1997). Additionally, firms with strong knowledge assimilation capabilities are better able to analyze, process, interpret, and understand new technologies (Zahra and George, 2002). They are also better able to overcome differences in the heuristics underlying new technologies, as well as problems arising from their context specificity (Szulanski, 1996).

Consequently, firms with superior knowledge acquisition and assimilation capabilities will be better able to create value with market capability leveraging technological innovation. Since these two capabilities comprise potential absorptive capacity, it follows that firms with superior potential absorptive capacity will display superior complementarity to market capability leveraging technological innovation. (This scenario is depicted in the top right square of Figure 5).

Proposition 2: When firms pursuing market capability leveraging technological innovation embody a new technology in successful products addressing a given market, firms with superior potential absorptive capacity will appropriate more value than other innovating firms. 


\section{Figure 5: Dynamic Capabilities and Value Appropriation}

\begin{tabular}{|c|c|c|c|}
\hline & \multicolumn{3}{|c|}{ Technical } \\
\hline & & $\begin{array}{c}\text { Strong } \\
\text { capabilities }\end{array}$ & $\begin{array}{c}\text { Weak } \\
\text { capabilities }\end{array}$ \\
\hline $\begin{array}{c}\text { Strong } \\
\text { capabilities }\end{array}$ & $\begin{array}{l}\text { Technology } \\
\text { (P5b) }\end{array}$ & suppliers appropriate & $\begin{array}{l}\text { Superior potential absorptive } \\
\text { capacity } \rightarrow \text { superior appropriation } \\
(\mathrm{P} 2)\end{array}$ \\
\hline Market & & & \\
\hline $\begin{array}{c}\text { Weak } \\
\text { capabilities }\end{array}$ & $\begin{array}{l}\text { Superior } \\
\text { capacity } \rightarrow \\
\text { (P3) }\end{array}$ & $\begin{array}{lr}\text { realized absorptive } \\
\text { superior appropriation }\end{array}$ & $\begin{array}{l}\text { Superior absorptive capacity } \rightarrow \\
\text { superior appropriation }(\mathrm{P} 4) \\
\text { Similar absorptive capacity } \rightarrow \text { tech. } \\
\text { suppliers appropriate }(\mathrm{P} 5 \mathrm{a})\end{array}$ \\
\hline
\end{tabular}

Technical capability leveraging technological innovation. Technical capability leveraging technological innovation entails the exploration of new market capabilities and the exploitation of technical capabilities. Firms with highly developed capabilities in a technological domain will more easily assimilate new technologies in that domain (Cohen and Levinthal, 1990). They will have superior design and engineering know-how, will have well-established routines for working with similar technologies, and will be better able to evaluate the technical feasibility and resource requirements for working with new technologies in that domain (Clark, 1987; Danneels, 2002).

However, their poorer market capability endowments will impede the accurate evaluation of market characteristics, customer preferences, and prevailing purchase procedures (Danneels, 2002). They may also lack the capacity to manage market-specific distribution, sales, and customer communication channels (Clark, 1987). In addition to the lack of complementary resources for addressing customers, market capability learning will require a broader scope of search than would otherwise have been the case (Katila and Ahuja, 2002).

These problems can be greatly alleviated by firms' knowledge transformation and exploitation capabilities. Firms with well-developed knowledge transformation capabilities are better able to cross-apply existing knowledge to new market applications (Zahra and George, 2002). Through the process of "bisociation," transformation capabilities facilitate the recognition of new opportunities and enable firms to see themselves and their competitive landscape in new ways, thus easing the generation of new market competencies (Koestler, 1966; Zahra and George, 2002). Similarly, knowledge exploitation capabilities help firms to refine, extend, and leverage existing competencies (Zahra and George, 2002). Through knowledge exploitation, firms can create new market capabilities by incorporating transformed knowledge into operations (Jansen et al., 2005). In addition, exploitation capabilities enable firms to retrieve previously learned/stored knowledge which may be useful in new situations; as well as to use market, customer, and competitor knowledge to create new competencies (Zahra and George, 2002).

Since knowledge transformation and exploitation capabilities comprise realized absorptive capacity, it therefore follows that firms with superior realized absorptive capacity will display 
superior complementarity to technical capability leveraging technological innovation (bottom left square of Figure 5).

Proposition 3: When firms pursuing technical capability leveraging technological innovation embody a new technology in successful products addressing a given market, firms with superior realized absorptive capacity will appropriate more value than other innovating firms.

Exploratory technological innovation. Firms pursuing exploratory technological innovation face the problems associated with the exploration of technical capabilities simultaneously with those associated with market capability exploration. As such, in order to cope effectively, they require well-developed knowledge acquisition and assimilation capabilities, as well as strong knowledge transformation and exploitation capabilities. Thus complementarity will be driven by both potential and realized absorptive capacity. Consequently, firms with superior endowments of potential absorptive capacity and realized absorptive capacity will outperform other firms pursuing exploratory technological innovation (bottom right square of Figure 5).

Proposition 4: When firms pursuing exploratory technological innovation embody a new technology in successful products addressing a given market, firms with superior potential and realized absorptive capacity will appropriate more value than other innovating firms.

Innovating for suppliers. Finally, there are two situations when innovating firms may not vary significantly in complementarity. Firstly, when firms pursuing exploratory technological innovation have similar levels of absorptive capacity, they will not vary greatly in their ability to tackle the challenges highlighted earlier with respect to market and technical capability exploration. As such, there will be little variation in their ability to create value and they will exhibit comparable complementarity (or lack thereof).

Secondly, when firms pursue exploitative technological innovation, they will all be able to speedily and efficiently acquire and assimilate a new technology (Clark, 1987; Danneels, 2002). In addition, they will all have a good knowledge of customer needs and preferences, along with strong capabilities of addressing a given market (ibid). As such, though they may all create very valuable innovations, they will not differ greatly amongst themselves in complementarity.

Adegbesan (2005) shows that when innovating firms are similar in complementarity, ${ }^{\Delta V_{i j}}$ in Figure 3 will not vary significantly across firms, such that $\Delta V_{i j} \approx \delta_{1} \approx \delta_{0}$. As a consequence, in the absence of unlimited technology supply, most of the value created by innovation will be appropriated by technology suppliers. As such we expect that

Proposition 5a: When firms with similar levels of absorptive capacity pursuing exploratory technological innovation embody a new technology in successful products addressing a given market, a disproportionate share of the returns will be appropriated by suppliers of the new technology.

Proposition 5b: When firms pursuing exploitative technological innovation embody a new technology in successful products addressing a given market, a disproportionate share of the returns will be appropriated by suppliers of the new technology. 


\section{Discussion}

Our findings in this paper suggest that a firm's ability to appropriate value from external technology depends on the fit between its innovation strategy and its investments in various dimensions of absorptive capacity. Firms pursuing exploitative technological innovation are better able to appropriate value than firms pursuing other innovation strategies (Proposition 1), but they are also more vulnerable to competency traps. Excessive exploitation to the point of strategic similarity shifts appropriation from innovating firms to technology suppliers (Proposition 5b). Thus what was the best strategy for appropriation could become the worst, if pursued by many firms.

Innovating firms may therefore give up some present appropriation gains for future appropriation (learning) gains by pursuing capability leveraging technological innovation. However, when firms do this, the lack of distinctive capability excellence shifts the locus of appropriation to excellence in dynamic capabilities (Propositions 2, 3, and 4). As such, when firms pursue market capability leveraging technological innovation, those with superior potential absorptive capacity will profit most (Proposition 2); and when they pursue technological capability leveraging technological innovation, those with superior realized absorptive capacity will profit most (Proposition 3).

When firms pursue (purely) exploratory technological innovation, those with superior complementarity will be the firms that exhibit both superior potential and realized absorptive capacity. However, it is difficult for firms to outperform all their peers on both counts. Hence there could very easily be strategic similarity among firms pursuing exploratory technological innovation, either because they equally exhibit poor complementarity, or because some firms' excellence in potential absorptive capacity is matched by other firms' excellence in realized absorptive capacity. Thus, while exploratory technological innovation potentially has the greatest learning gains, it can also result in handing over value appropriation to technology suppliers (Proposition 5a).

Consequently value appropriation (and hence performance) is not driven by new technologies per se, but by the capabilities and dynamic capabilities firms use to mold them into concrete products directed at specific markets.

These clarifications are important in view of the excitement over the possibilities for increased innovation provided by the proliferation of knowledge workers and the rise of markets for technology. The focus on increasing innovativeness often overlooks the question of who benefits from increases in innovative output. As Winter has pointed out, "no matter how great the technology or how big the market for it, there is no guarantee that the value from a new technology will go to the innovator" (Winter, 2000a: 242).

Poor appropriation may also explain current managerial dissatisfaction with returns on innovation. For example, a recent global study by the Boston Consulting Group found that less than half of executives surveyed were satisfied with returns on innovation; and concluded that "the unspoken truth seems to be that for a very large number of companies, innovation spending continues to rise, but it is generating neither enough profit nor competitive advantage" (Andrew, 2005: 7).

With the previous emphasis on internal R\&D, firms that created new technology often also embodied them in innovative products and services. Thus most previous research focused on factors affecting imitability and value appropriation for the technology supplier. However, with 
the rise of markets for technology and the "open innovation" paradigm, it becomes critical to analyze how firms can appropriate value from external technology which is often also accessible to their competitors.

In this line, we emphasize the importance of the interaction between innovation strategy and investments in potential and/or realized absorptive capacity. Firms need to invest in absorptive capacity in line with their innovation strategies, and/or derive their innovation strategies in view of their absorptive capacity endowments. Firms should also direct their innovation strategies towards the development of technical and market capabilities for future value appropriation.

Thus innovation should not be seen only in terms of new technologies and innovative output, but more specifically in terms of building, linking, and leveraging first-order capabilities and dynamic capabilities across technologies and markets. Whereas an excessive focus on particular technologies benefits suppliers, a focus on the idiosyncratic market and technical capabilities for molding new technologies into products, provides firms with a locus of differentiation and value appropriation.

Despite the current emphasis on external sourcing, it is important to remember that superior appropriation is impossible in the absence of heterogeneity (Peteraf, 1993), and so firms cannot "buy" competitive advantage (Barney, 1989; Dierickx and Cool, 1989). Thus we suggest that rather than outside, the locus of superior performance is moving deeper inside the firm, to the fit between higher order capabilities and external resources. When a few firms could control the best technologies in-house, their technological superiority served to differentiate them. However, as technological frontiers have migrated beyond the control of any group of firms, market, as well as technical, capabilities have become key. We suggest that to the extent (or in domains where) firms exhibit similar capabilities, the locus of appropriation shifts to superiority in dynamic capabilities. Even so, it is "not necessarily advantageous for a firm to invest in ... dynamic capabilities" (Winter, 2003: 993). In other words, their being "dynamic" alone doesn't necessarily make them more valuable. We show that appropriation depends on which dynamic capabilities are involved, when, and whether competitors exhibit them or not.

For this reason we also believe that Zahra and George's (2002) reconceptualization of absorptive capacity is useful, because by breaking it into its constituent parts we can see that absorptive capacity is not a "rule for riches." The ability to profit from external knowledge does not always improve performance, but depends on the locus of that ability (potential or realized), as well as on whether others display it or not. Performance is improved when absorptive capacity is present in a dimension that creates value in a given context, and when it is possessed by one firm to a greater degree than by other firms in that context. Thus the fact that absorptive capacity is a good predictor of innovative output doesn't necessarily mean it will predict performance (as measured by value appropriation) equally well.

In fact our study suggests that innovative output might be problematic as a proxy for the performance outcomes of various firm strategies. Although there are very good reasons for its usage (e.g. it is relatively easy to measure, and it is often difficult to get other proxies), our study calls for caution, because the level of innovative output can be endogenous to firm innovation strategies (for example when firms give up present innovation performance for learning gains). This problem, however, can be alleviated by using longitudinal measures of innovative output, since true learning gains should eventually show up in improved performance at some point in time. 
Our findings also suggest that when innovating firms are similar in their ability to create value with a technology, those who smile all the way to the bank will be the technology suppliers. This is consistent with anecdotal evidence that during the Internet boom at the end of the 1990s, mature firms that sought to become "e-businesses" en masse, benefited much less than the technology firms and consultancies that "enabled" their e-business strategies. When new technologies are touted to boost the value creating ability of all firms, "techies" rather than innovating companies will probably be the ones to get rich (Winter, 2000a).

From a methodological standpoint, our study highlights the utility of the integration of cooperative game theory into the RBV, represented by the recent bargaining perspective on resource advantage (Lippman and Rumelt, 2003a). By viewing firms as coalitions of resources and capabilities that exhibit some degree of co-specialization, we were able to conceptualize technological innovation in terms of the combination of resources and capabilities of varying complementarity, within or across firm boundaries. This in turn allowed us to characterize innovation strategy in terms of its capability learning (Winter, 2000b) characteristics. We also drew on related work (Adegbesan, 2005) that uses the bargaining perspective to examine strategic factor markets characterized by resource complementarity. This enabled us to shed light on value appropriation, which is an under-researched area in strategy in general, and the RBV in particular (Coff and Lee, 2003).

Our use of the bargaining perspective, however, has a limitation which this approach shares with cooperative game-theoretic approaches in general. In the bargaining perspective, the amount of surplus created is assumed to be known, in order to focus on how heterogeneous resource endowments affect firms' ability to lay claim to it. In other words, "surplus is known, but its division is subject to negotiation" (Lippman and Rumelt, 2003: 1070). Thus in our case, players know those firms to which the new technology is more valuable, and this is used to bargain in each player's interest. Nevertheless, since our theory concerns the drivers of value appropriated, our results depend not on the knowledge of the exact amount of value created by various combinations, but on the particular knowledge of which players are more valuable than others, and to what extent.

Knowledge characteristics are an underdeveloped aspect of cooperative game theory (Brandenburger and Stuart, 2004), but this may still be a small price to pay for the power of the coalitional approach. In this paper for example, we are able to investigate multi-level appropriation, focusing not only on differences in value appropriation between innovating firms and technology suppliers, but also on differential appropriation amongst innovating firms themselves. Thus using the bargaining perspective, we capture both firm- and industry-level variation in value appropriation.

Future research could further explore differential effects of the dimensions of absorptive capacity. Apart from Jansen et al. (2005) who study antecedents of the various dimensions, there is almost no published work that explores if, when, and how, heterogeneous endowments in the various dimensions of absorptive capacity could affect firm performance. In addition, although research on capabilities in general, and dynamic capabilities in particular is "a particularly important theme" (Hoopes et al., 2003: 897) in the RBV, we need more work that goes beyond merely relating dynamic capabilities to performance, to distinguishing which dynamic capabilities are important in which contexts. Finally, the tradeoffs involved in choosing innovation strategies highlight the importance and need for research capable of capturing learning benefits in performance measures. Otherwise, the "net present performance" of firms which invest in learning will be underestimated, while the performance of firms that exploit present opportunities without preparing for the future will be over-estimated. 
In summary, our findings call for strategic navigation of technology markets opened up by the acceleration of technical advancement and the rise in the number and mobility of knowledge workers. "Open innovation" has been defined as "the use of purposive inflows and outflows of knowledge to accelerate internal innovation, and expand the markets for external use of innovation, respectively" (Chesbrough, 2006: 1). We suggest that while firms may profitably use the new markets to exploit under-utilized in-house technologies, they should be much more circumspect about the technologies they source and where they deploy them, as not every technology is equally "good" for every firm.

\section{Conclusion}

In this paper we have explored the drivers of value appropriation when firms innovate based on external new technologies. Building on the recent bargaining perspective on resource advantage, we conceptualized technological innovation in terms of the combination of resources and capabilities within and across firms. By focusing on the interactions between the various dimensions of absorptive capacity, and the capability-learning characteristics of various innovation strategies, we were thus able to show when firms innovating based on external technologies would appropriate more value than other innovating firms; and when technology suppliers would appropriate more value than innovating firms. 


\section{References}

Adegbesan, J. T. 2005, Strategic Factor Markets: Bargaining, Scarcity, and Resource Complementarity, Working Paper, IESE Business School, University of Navarra, Barcelona.

Ahuja, G., Coff, R. W. and Lee, P. M. 2005, "Managerial Foresight and Attempted Rent Appropriation: Insider Trading on Knowledge of Imminent Breakthroughs," Strategic Management Journal, 26: 791-808.

Andrew, J. P. 2005, Innovation 2005, Senior Management Survey, Boston Consulting Group Inc.

Argyris, C. and Schon, D. 1978, Organizational Learning, Reading, MA.: Addison-Wesley.

Arora, A., Ceccagnoli, M. and Cohen, W. M. 2003, R\&D and the Patent Premium, Working Paper 9431, National Bureau of Economic Research, Available at: http://www.nber.org/papers/w9431

Arora, A., Fosfuri, A. and Gambardella, A. 2001, "Markets for technology and their implications for Corporate Strategy," Industrial and Corporate Change, 10(2): 419-451.

Arora, A. and Gambardella, A. 1994, "Evaluating Technological Information and Utilizing It: Scientific Knowledge, Technological Capability and External Linkages in Biotechnology," Journal of Economic Behavior and Organization, 24(1): 91-114.

Barney, J. B. 1986, "Strategic Factor Markets: Expectations, Luck, and Business Strategy," Management Science, 32(10): 1231-1241.

Barney, J. B. 1988, "Returns to Bidding Firms in Mergers and Acquisitions: Reconsidering the Relatedness Hypothesis," Strategic Management Journal, 9: 71-78.

Barney, J. B. 1989, "Asset Stocks and Sustained Competitive Advantage: A Comment," Management Science, 35(12): 1511-1513.

Barney, J. B. 1991, "Firm Resources and Sustained Competitive Advantage," Journal of Management, 17(1): 99-120.

Brandenburger, A. and Stuart, H. W., Jr. 2003, Biform Games, Working Paper, New York University and Colombia University, Available at: www.stern.nyu.edu/ abranden:15/1/04

Brandenburger, A. M. and Nalebuff, B. J. 1996, Co-opetition, New York: Currency-Doubleday.

Brandenburger, A.M. and Stuart, H.W., Jr. 1996, "Value-Based Business Strategy," Journal of Economics and Management Strategy, 5(1): 5-24.

Burgelman, R. A., Maidique, M. A. and Wheelwright, S. C. 2001, Strategic Management of Technology and Innovation, Boston: McGraw Hill/Irwin.

Cassiman, B. and Veugelers, R. 2002, Complementarity in the Innovation Strategy: Internal $R \& D$, External Technology Acquisition, and Cooperation in R\&D, Working Paper.

Caves, R. E., Crookell, H. and Killing, P. J. 1983, "The Imperfect Market for Technology Licenses," Oxford Bulletin of Economics and Statistics, 45(3): 249-267.

Chesbrough, H. W. 2003, Open Innovation: The New Imperative for Creating and Profiting from Technology, Boston, MA: Harvard Business School Press.

Chesbrough, H. W. 2006, "Open Innovation: A New Paradigm for Understanding Industrial Innovation," In H. W. Chesbrough, W. Vanhaverbeke and J. West (Eds.), Open Innovation: Researching a New Paradigm: 1-12. Oxford: Oxford University Press. 
Chesbrough, H. W., Vanhaverbeke, W. and West, J. (Eds.). 2006, Open Innovation: Researching a New Paradigm, Oxford: Oxford University Press.

Clark, K. B. 1987, "Investment in New Technology and Competitive Advantage," In D. J. Teece (Ed.), The Competitive Challenge: Strategies for Industrial Innovation and Renewal: 59-81. Cambridge, MA: Ballinger Publishing Company.

Cockburn, I. M. and Henderson, R. M. 1998, “Absorptive Capacity, Coauthoring Behavior, and the Organization of Research in Drug Discovery," Journal of Industrial Economics, 46(2): 157-182.

Coff, R. W. 1999, “When Competitive Advantage Doesn't Lead to Performance: The Resourcebased View and Stakeholder Bargaining Power," Organization Science, 10(2): 119-133.

Coff, R. W. and Lee, P. M. 2003, "Insider Trading as a Vehicle to Appropriate Rent from R\&D," Strategic Management Journal, 24: 183-190.

Cohen, W. M. and Levinthal, D. A. 1989, "Innovation and Learning: The Two Faces of R\&D," Economic Journal, 99: 569-596.

Cohen, W. M. and Levinthal, D. A. 1990, “Absorptive Capacity: A New Perspective on Learning and Innovation," Administrative Science Quarterly, 35(1): 128-152.

Cohen, W. M., Nelson, R. R. and Walsh, J. P. 2000, Protecting their Intellectual Assets: Appropriability Conditions and Why U.S. Manufacturing Firms Patent or Not, Working Paper 7552, National Bureau of Economic Research, Available at: http://www.nber.org/papers/w7552

Conner, K. R. 1991, “A Historical Comparison of Resource-based Theory and Five Schools of Thought within Industrial Organization Economics: Do we have a New Theory of the Firm?" Journal of Management, 17(1): 121-154.

Danneels, E. 2002, “The Dynamics of Product Innovation and Firm Competences," Strategic Management Journal, 23(12): 1095-1121.

Denrell, J., Fang, C. and Winter, S. G. 2003, “The Economics of Strategic Opportunity,” Strategic Management Journal, 24: 977-990.

Dierickx, I. and Cool, K. 1989, "Asset Stock Accumulation and Sustainability of Competitive Advantage," Management Science, 35(12): 1504-1511.

Dougherty, D. 1992, “A Practice-Centered Model of Organizational Renewal through Product Innovation,” Strategic Management Journal, 13(Summer Special Issue): 77-92.

Drucker, P. F. 1954, The Practice of Management, New York: HarperCollins.

Drucker, P. F. 1985, Innovation and Entrepreneurship, New York: Harper and Row.

Eisenhardt, K. M. and Martin, J. A. 2000, “Dynamic Capabilities: What are they?" Strategic Management Journal, 21(10/11): 1105-1121.

Ghemawat, P. 1986, “Sustainable Advantage," Harvard Business Review, Vol. 64: 53-58.

Ghemawat, P. 1991, Commitment: The Dynamic of Strategy, New York: Free Press.

Grant, R. M. 2002, Contemporary Strategy Analysis: Concepts, Techniques, Applications, (4th ed.). Oxford: Blackwell.

Hamel, G. 2000, Leading the Revolution, Boston: Harvard Business School Press.

Henderson, R. M. and Cockburn, I. M. 1994, "Measuring Competence? Exploring Firm Effects in Pharmaceutical Research," Strategic Management Journal, 15: 63-84. 
Hoopes, D. G., Madsen, T. L. and Walker, G. 2003, "Guest Editors' Introduction to the Special Issue: Why is there a Resource-based View? Toward a Theory of Competitive Heterogeneity," Strategic Management Journal, 24: 889-902.

Jansen, J. J. P., Van Den Bosch, F. A. J. and Volberda, H. W. 2005, "Managing Potential and Realized Absorptive Capacity: How Do Organizational Antecedents Matter?" Academy of Management Journal, 48: 999-1015.

Kandybin, A. and Kihn, M. 2004, “Raising Your Return on Innovation Investment," Strategy+Business(35): 1-12.

Katila, R. and Ahuja, G. 2002, "Something Old, Something New: A Longitudinal Study of Search Behavior and New Product Introduction," Academy of Management Journal, 45: 1183-1194.

Kim, L. 1997, "The Dynamics of Samsung's Technological Learning in Semiconductors," California Management Review, 39(3): 86-100.

Kim, W. C. and Mauborgne, R. 1999, "Strategy, Value Innovation, and the Knowledge Economy," Sloan Management Review, 40(3): 41-54.

Koestler, A. 1966, The Act of Creation, London: Hutchinson.

Kogut, B. and Zander, U. 1992, "Knowledge of the Firm, Combinative Capabilities, and the Replication of Technology," Organization Science, 3: 383-397.

Kreps, D. 1990, A Course in Microeconomic Theory, Princeton: Princeton University Press.

Lane, P. J. and Lubatkin, M. 1998, "Relative Absorptive Capacity and Interorganizational Learning,” Strategic Management Journal, 19: 461-477.

Lane, P. J., Salk, J. E. and Lyles, M. A. 2001, “Absorptive Capacity, Learning, and Performance in International Joint Ventures,” Strategic Management Journal, 22: 1139-1161.

Laursen, K. and Salter, A. 2006, "Open for Innovation: The Role of Openness in Explaining Innovation Performance among UK Manufacturing Firms," Strategic Management Journal, 27: 131-150.

Lenox, M. and King, A. 2004, "Prospects for Developing Absorptive Capacity through Internal Information Provision," Strategic Management Journal, 25: 331-345.

Leonard-Barton, D. 1992, "Core Capabilities and Core Rigidities: A Paradox in Managing New Product Development," Strategic Management Journal, 13(Summer Special Issue): 111-125.

Levin, R. C., Klevorick, A. K., Nelson, R. R. and Winter, S. G. 1987, "Appropriating the Returns from Industrial Research and Development," Brookings Papers on Economic Activity, 3: 783-820.

Linder, J. C., Jarvenpaa, S. and Davenport, T. H. 2003, "Toward an Innovation Sourcing Strategy," MIT Sloan Management Review, 44(4): 43-49.

Lippman, S. A. and Rumelt, R. P. 2003a, "A Bargaining Perspective on Resource Advantage," Strategic Management Journal, 24: 1069-1086.

Lippman, S. A. and Rumelt, R. P. 2003b, "The Payments Perspective: Micro-Foundations of Resource Analysis,” Strategic Management Journal, 24(October Special Issue): 903-927.

MacDonald, G. and Ryall, M. D. 2003, New Methods for the Identification and Evaluation of Strategic Initiatives, Working Paper, Washington University in St Louis and the University of Rochester. Available at: www.olin.wustl.edu/faculty/macdonald

MacDonald, G. and Ryall, M. D. 2004, "How do Value Creation and Competition Determine Whether a Firm Appropriates Value?” Management Science, 50(10): 1319-1333. 
Makadok, R. 2001, "Toward a Synthesis of the Resource-based and Dynamic-capability Views of Rent Creation," Strategic Management Journal, 22(5): 387-401.

Makadok, R. and Barney, J. B. 2001, "Strategic Factor Market Intelligence: An Application of Information Economics to Strategy Formulation and Competitor Intelligence," Management Science, 47(12): 1621-1638.

Makowski, L. and Ostroy, J. M. 2001, "Perfect Competition and the Creativity of the Market," Journal of Economic Literature, 39: 479-535.

March, J. G. 1991, "Exploration and Exploitation in Organizational Learning," Organization Science, 2(1): 71-87.

Maritan, C. A. and Brush, T. H. 2003, "Heterogeneity and Transferring Practices: Implementing Flow Manufacturing in Multiple Plants," Strategic Management Journal, 24: 945-959.

Markides, C. C. 1997, “Strategic Innovation,” Sloan Management Review, 38(3): 9-23.

McEvily, S. K. and Chakravarthy, B. 2002, "The Persistence of Knowledge-Based Advantage: An Empirical Test for Product Performance and Technological Knowledge," Strategic Management Journal, 23: 285-305.

McEvily, S. K., Eisenhardt, K. M. and Prescott, J. E. 2004, "The Global Acquisition, Leverage, and Protection of Technological Competencies," Strategic Management Journal, 25: 713-722.

Mowery, D. C., Oxley, J.E. and Silverman, B. S. 1996, "Strategic Alliances and Interfirm Knowledge Transfer," Strategic Management Journal, 17(Winter Special Issue): 77-91.

Nelson, R. R. and Winter, S. G. 1982, An Evolutionary Theory of Economic Change, Cambridge, MA: Belknap Press.

Nerkar, A. and Roberts, P. W. 2004, "Technological and Product-Market Experience and the Success of New Product Introductions in the Pharmaceutical Industry," Strategic Management Journal, 25: 779-799.

Peteraf, M. A. 1993, "The Cornerstones of Competitive Advantage: A Resource-Based View," Strategic Management Journal, 14: 179-191.

Peteraf, M. A. and Barney, J. B. 2003, “Unraveling the Resource-Based Tangle," Managerial and Decision Economics, 24: 309-323.

Pisano, G. P. 1990, "The R\&D Boundaries of the Firm: An Empirical Analysis," Administrative Science Quarterly, 35: 153-176.

Polanyi, M. 1962, Personal Knowledge: Toward a Post-Critical Philosophy, London: Routledge and Kegan Paul.

Quinn, J. B. 2000, "Outsourcing Innovation: The New Engine of Growth," Sloan Management Review, 41(4): 13-28.

Reed, R. and DeFillipi, R. J. 1990, "Causal Ambiguity, Barriers to Imitation, and Sustainable Competitive Advantage," Academy of Management Review, 15(1): 88-102.

Reuer, J. J. and Koza, M. P. 2000, “On Lemons and Indigestibility: Resource Assembly through Joint Ventures," Strategic Management Journal, 21: 195-197.

Rigby, D. and Zook, C. 2002, “Open-Market Innovation,” Harvard Business Review, 80(10): 80-89.

Robertson, T. S. and Gatignon, H. 1998, "Technology Development Mode: A Transaction Cost Conceptualization," Strategic Management Journal, 19: 515-531.

Rosenkopf, L. and Nerkar, A. 2001, "Beyond Local Search: Boundary-Spanning, Exploration, and Impact in the Optical Disk Industry,” Strategic Management Journal, 22: 287-306. 
Rothaermel, F. T. 2001, "Incumbent's Advantage through Exploiting Complementary Assets via Interfirm Cooperation,” Strategic Management Journal, 22(6/7): 687-699.

Stuart, H. W., Jr. 2001, “Cooperative Games and Business Strategy,” In K. Chatterjee and W. Samuelson (Eds.), Game Theory and Business Applications: 189-211: Kluwer Academic.

Szulanski, G. 1996, "Exploring Internal Stickiness: Impediments to the Transfer of Best Practice Within the Firm," Strategic Management Journal, 17: 27-43.

Teece, D. J. 1987, "Profiting from Technological Innovation: Implications for Integration, Collaboration, Licensing, and Public Policy," In D. J. Teece (Ed.), The Competitive Challenge: Strategies for Industrial Innovation and Renewal: 185-219. Cambridge, MA: Ballinger Publishing Company.

Teece, D. J. 2003, "The Strategic Management of Technology and Intellectual Property," In D. 0. Faulkner and A. Campbell (Eds.), The Oxford Handbook of Strategy, Vol. I: "A Strategy Overview and Competitive Strategy": 132-166. Oxford: Oxford University Press.

Teece, D. J., Pisano, G. and Shuen, A. 1997, “Dynamic Capabilities and Strategic Management," Strategic Management Journal, 18(7): 509-533.

Thomke, S. and Kuemmerle, W. 2002, "Asset Accumulation, Interdependence and Technological Change: Evidence from Pharmaceutical Drug Discovery," Strategic Management Journal, 23: 619-635.

Tsai, W. 2001, "Knowledge Transfer in Intraorganizational Networks: Effects of Network Position and Absorptive Capacity on Business Unit Innovation and Performance," Academy of Management Journal, 44: 996-1004.

Veugelers, R. 1997, "Internal R\&D Expenditures and External Technology Sourcing," Research Policy, 26: 303-315.

von Hippel, E. 1982, "Appropriability of Innovation Benefit as a Predictor of the Source of Innovation," Research Policy, 11(2): 95-115.

West, J. 2006, "Does Appropriability Enable or Retard Open Innovation?" In H. W. Chesbrough, W. Vanhaverbeke and J. West (Eds.), Open Innovation: Researching a New Paradigm: 109-133. Oxford: Oxford University Press.

Williamson, 0. 1985, The Economic Institutions of Capitalism, New York: Free Press.

Winter, S. G. 2000a, “Appropriating the Gains from Innovation,” In G. S. Day, P. J. H. Schoemaker and R.E. Gunther (Eds.), Wharton on Managing Emerging Technologies: 242-265. New York: Wiley.

Winter, S. G. 2000b, “The Satisficing Principle in Capability Learning," Strategic Management Journal, 21: 981-996.

Winter, S. G. 2003, “Understanding Dynamic Capabilities,” Strategic Management Journal, 24: 991-995.

Zahra, S. A. and George, G. 2002, "Absorptive Capacity: A Review, Reconceptualization, and Extension," Academy of Management Review, 27(2): 185-203. 